\title{
CORRELATION OF (PRO)RENIN RECEPTOR AND VASCULAR ENDOTHELIAL GROWTH FACTOR EXPRESSION LEVEL IN THIRD TRIMESTER OF PREECLAMPSIA PLACENTAS
}

\author{
NELLY MARISSA ${ }^{1,2 *}$, SRI WIDIA A JUSMAN ${ }^{3,4}$, YUDITIYA PURWOSUNU ${ }^{4,5}$, ANI RETNO PRIJANTI ${ }^{3,4}$ \\ ${ }^{1}$ Master Program in Biomedical Sciences, Faculty of Medicine, Universitas Indonesia, Jakarta, Indonesia. ${ }^{2}$ Balai Penelitian \& \\ Pengembangan Kesehatan Banda Aceh, Aceh Darussalam, Indonesia. ${ }^{3}$ Department of Biochemistry and Molecular Biology, Faculty of \\ Medicine, Universitas Indonesia, Jakarta, Indonesia. ${ }^{4}$ Department of Biochemistry and Molecular Biology, Centre of Hypoxia and Oxidative \\ Stress Studies, FKUI, Jakarta, Indonesia 10430. ${ }^{5}$ Department of Obstetrics and Gynaecology, Cipto Mangunkusumo Central Hospital - FMUI, \\ Jakarta, Indonesia. Email: nellymarissa@gmail.com
}

Received: 17 October 2018, Revised and Accepted: 03 August 2018

ABSTRACT

Objective: This cross-sectional study was designed to correlate the expression of mRNA and protein of (pro)renin receptor ([P]RR) and vascular endothelial growth factor (VEGF) gene in preeclampsia placentas.

Methods: We used 34 placenta tissues of normal pregnancy and 34 preeclampsia placenta tissues. Real-time polymerase chain reaction was used to measure relative expression of VEGF and (P)RR mRNAs, and protein concentration was measured using Sandwich ELISA technique.

Results: VEGF mRNA relative expression of preeclampsia placenta was 2.83 times higher than the normal placenta ( $\mathrm{p}=0.02)$. (P)RR mRNA relative expression on preeclampsia placenta was 1.7 times higher than the normal one $(\mathrm{p}=0.039)$. Expression of protein $(\mathrm{P}) \mathrm{RR}$ and VEGF was lower on preeclampsia shown by $\mathrm{p}<0.05, \mathrm{R}=0.441$. From this research, it was considered that low protein of (P)RR and VEGF contributes to preeclampsia.

Conclusion: There was a correlation between (P)RR and VEGF. It considers that there is any involvement of (P)RR on angiogenesis through VEGF expression in preeclampsia placenta.

Keywords: Preeclampsia, Placenta, Vascular endothelial growth factor, (Pro) renin receptor/(P)RR.

(C) 2018 The Authors. Published by Innovare Academic Sciences Pvt Ltd. This is an open access article under the CC BY license (http://creativecommons. org/licenses/by/4. 0/) DOI: http://dx.doi.org/10.22159/ajpcr.2018.v11i12.23173

\section{INTRODUCTION}

One of the major causes of maternal deaths is hypertension during pregnancy. Based on population census data in 2010,32\% of maternal mortality was caused by hypertension during pregnancy [1]. One of the hypertension complications during pregnancy is preeclampsia. The incidence rate of preeclampsia in developed countries is range from $2 \%$ to $8 \%$ [2]. A research conducted by Cho et al. showed that the incidence rate of preeclampsia in South Korea is 3.1\% [3]. In Indonesia, a research conducted by Warouw and team in RSUP Dr. R. D Kandau Manado showed that the incidence rate of preeclampsia was 6\%; meanwhile, a research conducted by Djannah in RSU PKU Muhammadiyah Yogyakarta concludes that the incidence rate of preeclampsia was $16.1 \%[4,5]$.

Clinically, preeclampsia is signed by a rise in blood pressure and proteinuria occurs after 20 weeks of pregnancy [5]. Genetically, in Indian woman, preeclampsia is associated with gene polymorphism, and there was significant association between vascular endothelial growth factor (VEGF-C) 405G and VEGF-C [6]. The exact cause of preeclampsia is not known yet until now but is likely to involve several factors such as antiphospholipid antibody syndrome, kidney disease, diabetes mellitus, obesity, systemic erythematosus, and nulliparity [7]. The imbalance of angiogenesis factor such as VEGF and renin-angiotensin system (RAS), and antiangiogenesis factor like sFltl-1 is expected as the cause of placenta failure, angiogenesis, and vasculogenesis $[8,9]$. In normal pregnancy, there is a correlation expression of (pro)renin receptor ([P]RR) with VEGF mRNA [10]. A research conducted by Kanda et al. on primary human retinal microvascular endothelial cells (HRMECs) concludes that there is a relation between the activity of (P) $\mathrm{RR}$ and angiogenesis on retinopathy diabetic [11]. The raise of prorenin concentration will increase the level of VEGF mRNA. That is, why it is believed that there is an involvement of (P)RR in VEGF regulation mechanism on pathogenesis preeclampsia so that this research is conducted to analyze the expression relation between (P)RR and VEGF on placenta of the third-semester pregnant woman with preeclampsia.

\section{METHODS}

This research was an observational study with control-case study design. It was conducted at the Laboratory of Molecular Biology for Oxidative Stress, Department of Biochemistry and Molecular Biology, Faculty of Medicine, Universitas Indonesia. It was conducted on January-April 2017. Samples used in this study were collected from the placenta tissues of woman with the third-trimester pregnancy divided into two groups: Normal and preeclampsia (biological material stored). There were 34 tissue's samples of normal pregnancy and 34 of preeclampsia pregnancy. This research has already approved by Health Studies, Faculty of Medicine Ethics Committee, Universitas Indonesia, number 104/UN2.F1/ETIK/2017.

The total RNA isolation process uses total RNA mini kit (Geneaid). The concentrationand purity ofRNA weremeasured usingVarioskan. Theaverage concentration of RNA total samples was 175.88 (14.025-588.7) $\mu \mathrm{g} / \mathrm{mL}$, while the average purity index was 1.874 (1.6-2.1)

The analysis of relative expression of (P)RR and VEGF mRNA was conducted with reverse transcriptase-PCR technique, using Sensifast ${ }^{\text {tm }}$ SYBR No-ROX one-step kit real-time polymerase chain reaction (qRTPCR) kit as same as Dongare et al. [12]. For analysis of (P)RR gene, the primer used was forward primer 5'-GAT GGT GAA GGG AGT GAA CAA-3' and reverse primer 5'-TGG AAT TTG CAA CAC TGT CAA G-3'. For analysis of VEGF gene, the primer used was forward primer 5'-CTG AGG TCT GCA TTC AC-3' and reverse primer 5'-CTT TGG TCT GCA TTC AC -3'. For reference gene, this research used 18s rRNA gene with primer: Forward 
primer 5'- AAA CGG CTA CCA CAT CCA AG- 3' and reverse primer 5'- CCT CCA ATG GAT CCT CGT TA-3'.

To each well, $10 \mu \mathrm{l}$ of SensiFAST SYBR No-ROX one-step mix was added along with $0.8 \mu \mathrm{L}$ forward primer $10 \mu \mathrm{M}, 0.8 \mu \mathrm{L}$ reverse primer $10 \mu \mathrm{mol}, 0.2 \mu \mathrm{L}$ reverse transcriptase, $0.4 \mu \mathrm{L}$ RiboSafe RNase inhibitor, $4 \mu \mathrm{L}$ of 10 ng RNA template, and $\mathrm{H}_{2} \mathrm{O}$ until the final volume reached $20 \mu \mathrm{L}$. The samples were analyzed in duplo, and non-template control was used as negative control. The samples were then incubated with qRT-PCR instrument (PCRmax) with protocol as followed: Reverse transcription step for $5 \mathrm{~min}$ at $42^{\circ} \mathrm{C}$; DNA polymerase activation at $95^{\circ} \mathrm{C}$ for $5 \mathrm{~min}$; denaturation at $95^{\circ} \mathrm{C}$ for $10 \mathrm{~s}$; primer annealing at the specific temperature (depends on the Tm of primers) for $10 \mathrm{~s}$; and extension step at $72^{\circ} \mathrm{C}$ for $30 \mathrm{~s}$. Steps from denaturation to extension were repeated for 40 cycles.

The gene expression analysis was measured with relative quantification by applying Livak method. First, the cycle threshold (Ct) numbers of targeted gene were normalized with the reference gene for analysis and calibration. After that, the analyzed $\Delta \mathrm{Ct}$ was normalized with $\Delta \mathrm{Ct}$ calibrator, hence, that the expression ratio could be measured by applying the formula of $2^{-\Delta \Delta \mathrm{Ct}}$.

For protein expression analysis, first, we made tissue homogenate for protein analysis by measuring $\pm 100 \mathrm{mg}$ of placenta tissue, then $500 \mu \mathrm{L}$ of PBS (PH 7,4; 0,01 M) were added and then the mixture was homogenated using micropestle and tissue homogenizer. Another $500 \mu \mathrm{L}$ of PBS was added after the homogenation, and then the mixture was centrifuged at $5000 \mathrm{~g}$ speed for $10 \mathrm{~min}$. The supernatant was taken for protein analysis.

The analysis of (P)RR and VEGF protein was conducted by applying Sandwich ELISA technique. $100 \mathrm{uL}$ standard or samples were pipetted into the wells and incubated for $90 \mathrm{~min}$ at $37^{\circ} \mathrm{C}$. Then, the standard solution and samples were disposed. After that, antibody solution labeled biotin that has been diluted using $100 \mu \mathrm{L}$ of biotin diluent (1:100) was added into each well, then incubated for $1 \mathrm{~h}$ at $37^{\circ} \mathrm{C}$. The solution was disposed and the washing step was performed by the addition of $350 \mu \mathrm{L}$ of wash buffer that has been diluted with aquabidest (1:25) and incubated at room temperature for 1-2 min and then discard the solution. This washing step then repeated for another 2 cycles, to do 3 times of washing step in total. The HRP solution that has been diluted with HRP diluent (1:100) was pipetted $100 \mu \mathrm{L}$ of into each well, then incubated for $30 \mathrm{~min}$ at $37^{\circ} \mathrm{C}$ and sealed with a sealer. The unbound HRP was discarded, and the plate was washed with 5 times of washing step as described above. The substrate was added $90 \mu \mathrm{L}$ into each well and incubated for $15 \mathrm{~min}$ using light protector. The stop solution was added $50 \mu \mathrm{L}$ of into each well to stop the reaction. The absorbance of each protein was measured with ELISA reader with wavelength of $450 \mathrm{~nm}$. The level of (P)RR protein and VEGF was determined at each samples using standard curve.

Normality test of all data was conducted with Kolmogorov-Smirnov test. If the data were normal, it would be presented in average and deviation standard. However, if the data were not normal, it would be presented in median and in range of minimum-maximum. Statistical analysis was incomplete, then the Mann-Whitney test applied. Statistical analysis for the correlation between two variables applied by Pearson test. The statistical significance limit applied was $\mathrm{p}<0.05$. All statistical analyses were processed using computer with social science (SPSS) software for Windows version 20 .

\section{RESULTS}

\section{VEGF and (P)RR mRNA relative expression}

The research concluded that there was a distinguished relative expression of relative mRNA VEGF between preeclampsia placenta and normal placenta. On placenta tissue with preeclampsia complication, VEGF mRNA expression increased 2.83 times higher than normal placenta (Fig. 1). Based on Mann-Whitney test, there was a substantial difference of mRNA VEGF median expression between preeclampsia group and normal ones $(\mathrm{p}=0.02)$.

Based on the analysis result, it was found out that mRNA (P)RR expression on preeclampsia placenta was 1.7 times higher than normal placenta. Based on Mann-Whitney test, there was a significant difference of median level of two groups at mRNA (P)RR.

In preeclampsia, the relative expression of mRNA VEGF was 2.83 times higher than the normal samples (Fig. 2).

\section{The protein level of VEGF and (P)RR}

Based on the result of protein analysis by applying Sandwich ELISA technique, we found out that there was a substantial difference of VEGF protein average between normal group and preeclampsia group $(p=0.0001)$ (Fig. 3). The VEGF protein expression on preeclampsia group was lower than the normal group. The same case also occurred with (P)RR protein concentration. On preeclampsia group, the (P) RR protein concentration average was lower than normal group $(\mathrm{p}=0.004)$ (Fig. 4).

Result data of VEGF protein (Fig. 3.) showed that there was a significant difference between preeclampsia and normal placenta, $p=0.0001$. VEGF protein expression in preeclampsia placentas was lower than in normal placentas.

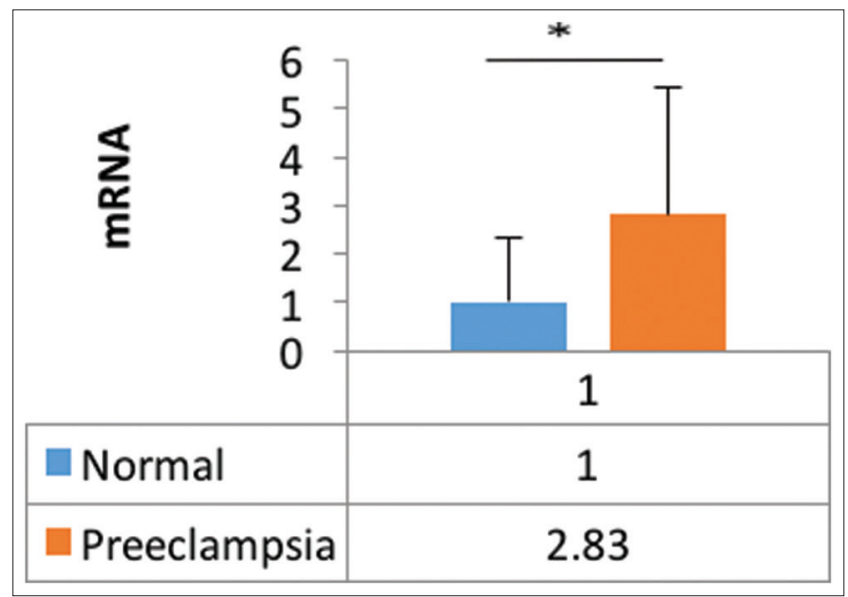

Fig. 1: Relative expression of vascular endothelial growth factor mRNA in preeclampsia placentas

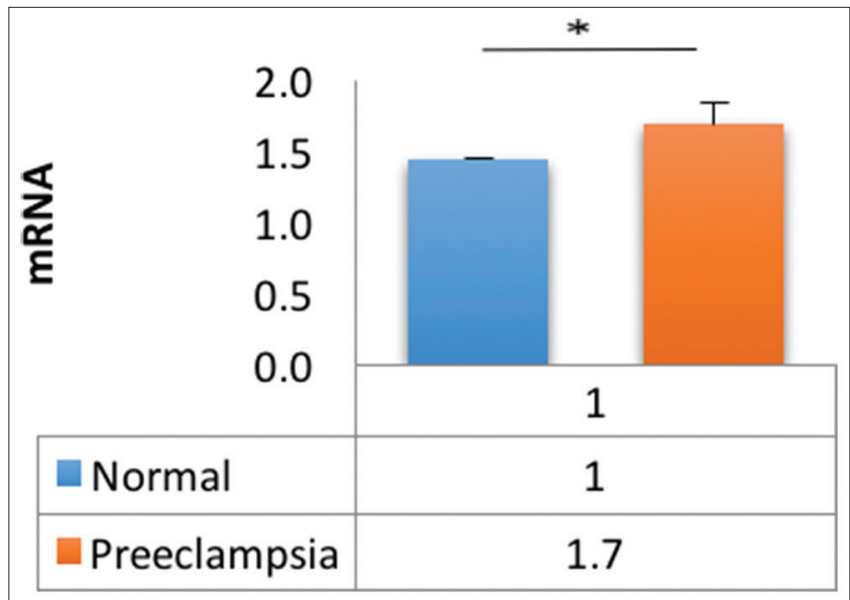

Fig. 2: Relative expression of (P)RR mRNA in preeclampsia placentas. Relative expression of mRNA (P)RR was 1.7 times higher than the normal samples 


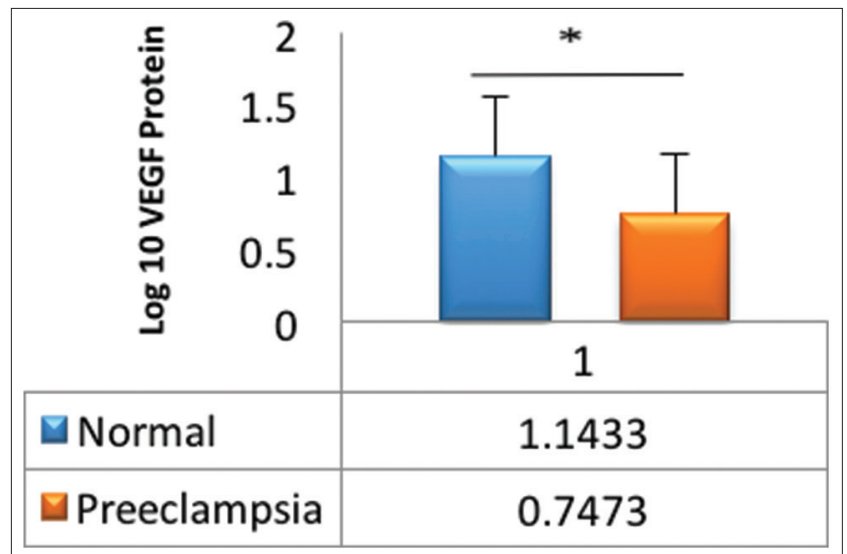

Fig. 3: Expression of vascular endothelial growth factor protein in preeclampsia placentas

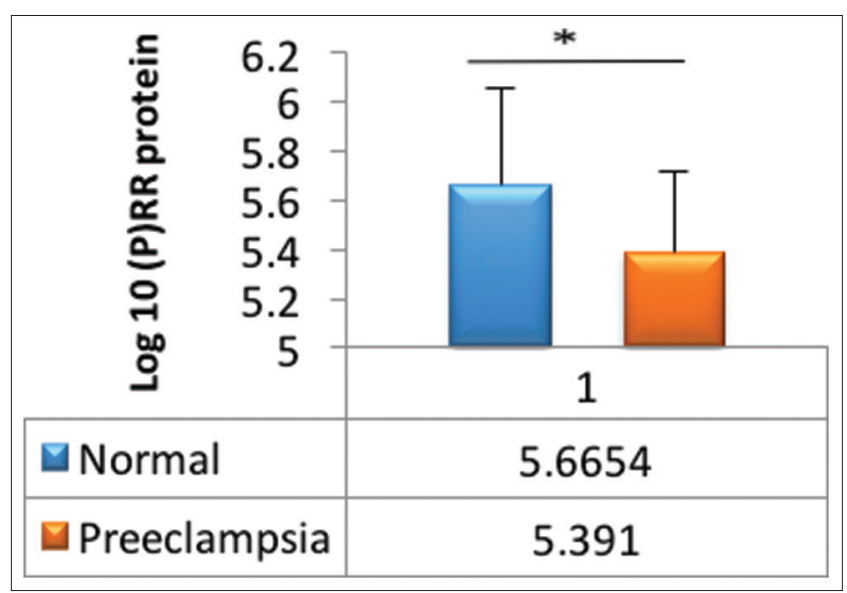

Fig. 4: Expression of (Pro)renin protein in preeclampsia placentas

\section{Correlation between expression of (P)RR and VEGF}

Based on Pearson correlation test result, it was concluded that there was no correlation between VEGF mRNA and (P)RR mRNA in normal or preeclampsia group. However, there was a substantial correlation of (P)RR and VEGF protein expression on normal and group with preeclampsia syndrome. On normal group, there was a positive strong correlation between (P)RR protein expression and VEGF protein expression $(\mathrm{p}=0.005 ; \mathrm{R}=0.441)$. On preeclampsia group, there was also a positive correlation of medium relation between $P(R R)$ and VEGF protein expression $(\mathrm{p}=0.012 ; \mathrm{R}=0.401)$.

\section{DISCUSSION}

Preeclampsia is a serious threat for pregnant women, even for health workers. Preeclampsia could cause significant effect on maternal morbidity and mortality. Besides, it could also cause prenatal, preterm birth, and other fetal growth problems [13].

Continuous implantation process with completed vasculogenesis and angiogenesis is the factors that create a good place for the fetus grows. Woman with VEGF gene polymorphism is often experience repeated abortion as the VEGF protein was the main growth factor in vasculogenesis and angiogenesis [14]. Protein VEGF has two receptors, Flt-1 and KDR/Flk-1. When VEGF protein was bound to its receptor, it could initiate the transduction signal on the endothelial cell to migrate and proliferate in vasculogenesis and angiogenesis process [15].

On normal trophoblast cell culture, VEGF mRNA expression could be found at cytotrophoblast and syncytiotrophoblast (STB) [16]. It showed that VEGF played an important role in vasculogenesis and angiogenesis process. Based on the analysis of VEGF mRNA expression in this research, it was concluded that there were substantial differences of VEGF mRNA expression between preeclampsia and normal group. The VEGF mRNA expression on preeclampsia group increased 2.83 times higher than normal group. The same conclusion was also stated by Chung et al. that there was an increase of VEGF mRNA expression 2.8 times higher than preeclampsia [17]. Escudero et al. also concluded that there was an increase of VEGF mRNA expression on women with preeclampsia syndrome in chili compared to the normal group [18]. On the other hand, Andraweera et al. who conducted research about group pregnant women in Adelaide Australia concluded differently that the expression of VEGF mRNA of placenta on preeclampsia was lower than the normal group [19].

In this research, protein concentration of VEGF placenta on preeclampsia group was lower than the normal one. The low concentration of VEGF protein on preeclampsia was expected related to the failure of angiogenesis. A research conducted by Gannoun et al., about Arabic Tunisian women, found that VEGF plasma concentration on preeclampsia was lower than normal pregnancy [20]. Livingston et al. who conducted a research of pregnant women in Ohio concluded that there was restriction of VEGF serum concentration on serious preeclampsia [21]. Maynard et al., in his research, stated that free VEGF on serum decreased on preeclampsia pregnancy. The increase of sFlt-1 that was alternatively spliced from Flt-1 caused the VEGF bound to Flt-1 decreases and ultimately might cause problems in signal transduction in vasculogenesis and angiogenesis process. It was also supported by the antiangiogenesis effect $48 \mathrm{~h}$ post-labor [22].

Another function of VEGF is for growth and proliferation of glomerulus and peritubular endothelial cell [23]. VEGF inhibitor could prevent neovascularization on tumor cell, while treatment of VEGF antagonist on cancer patient would cause proteinuria and hypertension, similarly as the symptoms in preeclampsia $[22,23]$. Pregnant mice that were induced with sFlt-1 would show glomerular enlargement with capillary occlusion due to hypertrophy on glomerulus capillary endothelial cell. There were also protein resorption problems on podocyte [22]. These factors were the cause of hypertension and proteinuria on preeclampsia $[24,25]$.

VEGF will influence the expression of nitrite oxide (NO). There was an increase on endothelial NO synthase (eNOS) expression on the cell that cultured and incubated with VEGF. It happened through the activation of PI3K and ERK phosphorylation [26]. When VEGF was bound to Flt-1 receptor which is a tyrosine kinase receptor, it might cause autophosphorylation of tyrosine794 residue (Tyr794). Then, PI3K will be activated, followed by AKT. Activated AKT would phosphorylate eNOS cause the NO production to increase. The same effect also happened when VEGF was bound to KDR/Flk-1 receptor [27]. On preeclampsia, one of the symptoms was hypertension; the decrease of VEGF protein expression could cause vasoconstriction due to the repression of NO expression. NO was main endothelial relaxation modular. It acts as paracrine and autocrine to protect cardiovascular homeostasis, tonus vascular muscle, and also microvascular permeability.

RAS or known as RAS plays a major role in pathogenesis preeclampsia. In early pregnancy, prorenin, (P)RR, and angiotensin II type 1 receptor were found on extravillous trophoblast (EVT). It explains the effect of RAS components in trophoblast migration [10]. In normal pregnancy, there was an increase of RAS components which were renin, angiotensinogen, angiotensin I, and aldosterone [28,29]. It does not happen to angiotensin-converting enzyme which its level remains the same as normal pregnancy. It explains why the increase of RAS components was not followed by hypertension in normal pregnancy [28].

(Pro)renin receptor which is the receptor of renin and prorenin was expected to play major role in implantation process. When the ligand was bound to (P)RR, it could raise the signal of angiotensin II (ANG II)dependent pathway and ANG II-independent pathway. It was expected to play a major role in vasculogenesis and angiogenesis process. In the research conducted in in vivo and in vitro, it was proven that prorenin 
bound to (P)RR plays a role in increasing neovascularization [30]. This role was supported by the existence of (P)RR at STB and EVT, and also (P)RR mRNA expression in normal pregnancy was higher at the early pregnancy than at the term pregnancy.

In this research, the (P)RR mRNA expression in preeclampsia pregnancy was higher than the normal group. On the other hand, the (P)RR protein expression was in preeclampsia was lower than in normal group. It shows that there were post-transcription arrangements in (P)RR expression. To fulfill its needs, cell tries to increase the expression of (P)RR mRNA in aiming that the protein expression would also increase. On the other hand, Thomason et al. analyzed the (P)RR protein expression in pregnant mice discovered that there was an elevation of (P)RR protein expression [29]. Nartita et al. analyzed (P)RR protein expression of Japanese women placenta and plasma also discovers that there was an escalation of (P)RR protein expression in preeclampsia, but there was no correlation between them [30].

(Pro)renin receptor existence is very important in placentation process. It is believed that there is a correlation between (P)RR expression and VEGF expression. A research conducted by Kanda et al., on HRMECs concluded that there was a correlation between the activity of (P)RR and angiogenesis on diabetic retinopathy. The elevation of protein concentration would increase the level of VEGF mRNA expression [11,31]. Binding of prorenin with (P)RR would stimulate ERK phosphorylation, also it will trigger an action without involving angiotensin 1 . The involvement of $(\mathrm{P}) \mathrm{RR}$ was proved by the inactivated (P)RR that would also inactivate ERK. Inhibitor (P)RR could suppress the expression of VEGF on pregnant diabetic mice. The resistance of VEGF expression occurred through the suppression of ERK $1 / 2$ phosphorylation $[32,33]$. This research also shows the relations between (P)RR protein expression and VEGF protein expression. There was positive correlation between normal group and preeclampsia with medium relation between (P)RR protein expression and VEGF protein expression. It proves that there was an involvement of (P)RR in VEGF expression arrangement on preeclampsia.

\section{CONCLUSION}

VEGF protein expression decreased in line with the decreasing of (P) RR protein expression on the placenta of the third-trimester pregnant women with preeclampsia. There was a correlation between the expression of (P)RR and VEGF.

\section{ACKNOWLEDGMENTS}

We wish to express our gratitude to the Directorate of Research and Public Service University of Indonesia for the Research Grant. This research was funded by grants of PUPT-DIKTI in 2017 and PITTA in 2016. Therefore, we would like to extend our gratitude to Kemenristek Dikti and Universitas Indonesia. In addition, there is no conflict of interest in this research.

\section{AUTHORS' CONTRIBUTION}

Author contributions were as follows: Nelly Marissa measured mRNA relative expression and ELISA of markers, Sri Widia A Jusman data analysis and correction, Yuditiya Purwosunu collect the samples, and Ani Retno Prijanti searched foundation as person in charge and manuscript correction.

\section{REFERENCES}

1. WHO. Maternal and Reproductive Health. Geneve; WHO; 2015. Available from: http://www.who.int/gho/maternal health/en/.

2. Chen CW, Jaffe IZ, Karumanchi SA. Pre-eclampsia and cardiovascular disease. J Cardiovasc Res 2014;101:579-86.

3. Cho GJ, Park JH, Shin SA, Oh MJ, Seo HS. Metabolic syndrome in the non-pregnant state is associated with the development of preeclampsia. Int J Cardiol 2016;203:982-6.

4. Warouw PC, Suparman E, Wagey FW. Characteristics of preeclampisa in RSUP PROF. Dr. R. D. Kandau Manado. J E Clinic 2016;4:1-7.
5. Djannah SN, Arianti IS. Epidemiology of preclampsia/eclampsia incidences in PKU Muhammadiyah general hospital in Yogyakarta during 2007-2009. Bull Penelit Sist Kesehat 2010;13:378-85.

6. Andraweera PH, Dekker GA, Laurence JA, Robert CT. Plecental expression of VEGF family mRNA in adverse pregnancy outcomes. Placenta 2012;33:467-72.

7. Uzan J, Carbonnel M, Piconne O, Asmar R, Ayoubi JM. Pre-eclampsia: Pathophysiology, diagnosis, and management. J Vasc Heal Risk Manag 2011;7:467-74

8. Baumfeld Y, Novack L, Wiznitzer A, Sheiner E, Henkin Y, Sherf M, et al. Pre-conception dyslipidemia is associated with development of preeclampsia and gestational diabetes mellitus. PLoS One 2015; 10:e 0139164

9. Rodriguez M, Moreno J, Hasbun J. RAS in pregnancy and preeclampsia and eclampsia. Int J Hypertens 2012;2012:1-6.

10. Zárate A, Saucedo R, Valencia J, Manuel L, Hernández M. Early disturbed placental ischemia and hypoxia creates immune alteration and vascular disorder causing preeclampsia. Arch Med Res 2014;45:519-24

11. Pringle KG, Tadros MA, Callister RJ, Lumbers ER. The expression and localization of the human placental prorenin/renin-angiotensin system throughout pregnancy: Roles in trophoblast invasion and angiogenesis ? J Placenta 2011;32:956-62.

12. Dongare S, Rajendran S, Senthilkumari S, Gupta SK, Mathur R, Saxena R, et al. Genistein alleviates high glucose induced toxicity and angiogenesis in cultured human RPE cells. Int J Pharm Sci 2015;7:294-8.

13. Kanda A, Noda K, Saito W, Ishida S. (Pro)renin receptor is associated with angiogenic activity in proliferative diabetic retinopathy. Diabetologia 2012;55:3104-13.

14. Sun Y, Chen M, Mao B, Cheng X, Zhang X, Xu C. Association between vascular endothelial growth factor polymorphism and recurrent pregnancy loss: A systematic review and meta-analysis. Eur J Obstet Gynecol Reprod Biol 2017;211:169-76.

15. Gavalas NG, Liontos M, Trachana SP, Bagratuni T, Arapinis C, Liacos C, et al. Angiogenesis-related pathways in the pathogenesis of ovarian cancer. Int J Mol Sci 2013;14:15885-909.

16. Shorea VH, Wang C. Vascular their endothelial growth factor, human placenta trophoblast growth factor and receptors in isolated. Placenta 1997; 18:657-65.

17. Chung J, Song Y, Wang Y, Magness R, Zheng J. Differential expression of VEGF, EG-VEGF, and VEGF receptors in human placentas from normal and pre-eclamptic pregnancies. J Clin Endocrinol Metab 2004;85:2484-90.

18. Escudero C, Celis C, Saez T, San Martin S, Valenzuela FJ, Aguayo C, et al. Increased placental angiogenesis in late and early onset preeclampsia is associated with differential activation of vascular endothelial growth factor receptor 2. Placenta 2014:35:207-15.

19. Azliana AF, Zainul-Rashid MR, Chandramaya SF, Farouk WI, Nurwadah A, Wong YP, et al. Vascular endothelial growth factor expression in placenta of hypertensive disorder in pregnancy. Indian J Pathol Mycrobiol 2017;60:515-20

20. Gannoun M, Bourrelly S, Raguema N, Zitouni H, Nouvellon E, Maleh W. Placental Growth factor and vascular endothelial growth factor receptor-2 in human. Cytokine 2016;79:1-6.

21. Livingston J, Chin R, Haddad B, Mc Kinney E, Ahokas R, Sibai B. Reductions of vascular endothelial growth factor and placental growth factor concentrations in severe preeclampsia. Am J Obs Gynecol 2000; $183: 1-4$

22. Maynard SE, Min J, Merchan J, Lim KH, Li J, Mondal S, et al. Excess placental soluble fms-like hypertension, and proteinuria in. J Clin Invest 2003;58:564-81. Available from: http://www.jci.org/articles/ view/17189.

23. Schrijvers BF, Flyvbjerg A, De Vriese AS. The role of vascular endothelial growth factor (VEGF) in renal pathophysiology. Kidney Int 2004;65:2003-17.

24. Björndahl M, Cao R, Eriksson A, Cao Y. Blockage of VEGF-induced angiogenesis by preventing VEGF secretion. Circ Res 2004;94:1443-50.

25. Roberts JM, Rajakumar A. Preeclampsia and soluble fms-like tyrosine kinase 1. J Clin Endocrinol Metab 2009;94:2252-4.

26. Lin MI, Sessa WC. Vascular endothelial growth factor signaling to endothelial nitric oxide synthase: More than a FLeeTing moment. Circ Res 2006;99:666-8.

27. Irani RA, Xia Y. The functional role of the renin-angiotensin system in pregnancy and preeclampsia. Placenta 2008;29:763-71.

28. Shah DM, Wenzel K, Rajakumar A, Haase H, Geusens N, Hubner N, et al. Role of the renin-angiotensin system in the pathogenesis of preeclampsia role of the renin-angiotensin system in the pathogenesis 
of preeclampsia. Ren Physiol 2012;53715:614-25.

29. Uraoka M, Ikeda K, Nakagawa Y, Koide M. Prorenin induces ERK activation in endothelial cells to enhance neovascularization independently of the renin-angiotensin system. Biochem Biophys Res Commun 2009;390:1202-7.

30. Thomason J, Reyes M, Allen SR, Jones RO, Beeram MR, Kuehl TJ, et al. Elevation of (Pro)Renin and (Pro)renin receptor in preeclampsia. Am J Hypertens 2015;28:1277-84.

31. Nartita T, Ichihara A, Matsuoka K, Takai Y, Bokuda K, Morimoto S, et al. Placental (pro) renin receptor expression and plasma soluble (pro) renin receptor levels in preeclampsia. J Placenta 2016;37:72-8.

32. Kanda A, Ishida S. The vitreous renin-angiotensin system is mediated by soluble (pro)renin receptor in diabetic retinopathy: A new implication of the receptor-associated prorenin system. Taiwan J Ophthalmol 2013;3:51-3.

33. Satofuka S, Ichihara A, Nagai N, Ozawa Y, Fukamizu A, Tsubota K, et al. (Pro)renin receptor-mediated signal transduction and tissue reninangiotensin system contribute to diabetes-induced retinal inflammation. Diabetes 2009;58:1625-33. 